\title{
MANAJEMEN KERJA KEPALA MADRASAH DALAM MENERAPKAN BUDAYA ISLAMI DI MAS SALIMPAUNG KABUPATEN TANAH DATAR
}

\author{
${ }^{1}$ Zulhendri, ${ }^{2}$ Hasan Zaini, ${ }^{3}$ Marjoni Imamora \\ ${ }^{1}$ Guru MAN 2 Tanah Datar, ${ }^{2,3}$ IAIN Batusangkar \\ J1. Jenderal Sudirman, Limo Kaum, Lima Kaum, Kabupaten Tanah Datar, Sumatera Barat 27213 \\ e-mail: zulhendrieva@gmail.com
}

Asoen

\begin{abstract}
The departs from the constraints of the MAS Salimpaung in applying discipline specifically Islamic culture is the students are required to practice all the theories that have been learned to be practiced in their daily lives at school. Such as the obligation to shake hands by kissing hands before entering class, performing dhuha prayer, midnight prayer in congregation, and checking each student's activities in the form of Islam, both in the school environment and outside the school environment. Islamic culture is formed wherever students are. The formulation of Working Management of Head Master in Implementing Islamic Culture at MAS Salimpaung, is carried out by the foundation, committee and several related teachers. The results of the formulation are: routine, spontaneous, exemplary and conditioning activities. The formulation was carried out in the school by experiencing 3 obstacles, namely, there was no reference to the program as a comparison, it was not presented by people who were experienced in formulating and lacking precisely the time of deliberation, because it was carried out in the afternoon. Working management implementation of Head Master in Implementing Islamic Culture, that, routine activities that run at MAS Salimpaung such as every morning, pray before and after lessons, Dhuba prayer, memorizing letters, and midday prayers. This activity includes daily activities, while weekly activities such as mubadharah are attended by all monthly school residents such as every three months a student and teacher tent is held. Annual activities such as mabid in the month of Ramadan, the celebration of Idul Fitri adn Idul Adha. (3). The evaluate method of Working Management of Head Master in Implementing Islamic Culture at MAS Salimpaung is carried out by examining more deeply the constraints found in the field, as well as holding a monthly evaluation meeting with the MAS Salimpaung Foundation.
\end{abstract}

Keywords: Working Management, Islamic Culture, MAS Salimpaung

\section{PENDAHULAN}

Pendidikan merupakan sebuah proses dalam rangka meningkatkan kualitas hidup manusia, mendewasakan serta merubah perilaku dan adat budayanya. Sebagaimana tertuang dalam Undang Undang Republik Indonesia Nomor 20 Tahun 2003 Bab II, pasal 3 dinyatakan:
Pendidikan nasional berfungsi mengembangkan kemampuan dan membentuk watak serta peradaban bangsa yang bermartabat dalam rangka mencerdaskan kehidupan bangsa, bertujuan untuk berkembangnya potensi peserta didik agar menjadi manusia yang beriman dan bertakwa kepada Tuhan Yang maha Esa, 
berakhlak mulia, sehat, berilmu, cakap, kreatif, mandiri, dan menjadi warga Negara yang demokratis serta bertanggung jawab.

Pada kenyataannya, pendidikan bukanlah suatu proses yang sederhana, melainkan sebagai suatu sistem yang didalamnya mengandung kegiatan yang saling berkaitan yang dinamis dan penuh tantangan. Pendidikan tidaklah statis melainkan akan selalu berubah seiring dengan perkembangan zaman. Itulah sebabnya, pendidikan senantiasa memerlukan upaya perbaikan dan peningkatan sejalan dengan semakin tingginya tantangan dan tuntutan kehidupan manusia. Bicara tentang perbaikan dan peningkatan pendidikan, maka sekolah sebagai sentral dan wadah pendidikan formal atau menjadi elemen penting yang harus mendapatkan perhatian secara lebih serius dan bersungguh-sungguh (Nanang Fattah, 2004: 1).

Untuk itu pendidikan yang berkualitas merupakan suatu hal yang harus dilaksanakan. Berbagai upaya telah dilakukan oleh pemerintah, salah satunya dengan penyempurnaan sistem pendidikan nasional. Sekolah dipandang sebagai suatu organisasi yang membutuhkan pengelolaan, karena inti dari sekolah adalah mengelola sumber daya manusia (SDM) yang untuk menghasilkan lulusan yang berkualitas, sesuai dengan tuntutan kebutuhan masyarakat, serta pada gilirannya lulusan sekolah diharapkan dapat memberikan kontribusi kepada pembangunan bangsa (Nanang Fattah, 2004: 2).

Kepala Madrasah sebagai top leader sebuah sekolah mempunyai peranan penting sebagai pemimpin dalam mengelola SDM pada sekolah yang dipimpinnya. Disamping itu bertanggung jawab atas keseluruhan prilaku manajemen yang terjadi di sekolah. Melalui pengontrolan secara terus menerus dan sistematis terhadap berbagai hal, seperti kurikulum, sarana prasarana, kesiswaaan dan lain-lain. Kepala Madrasah juga merupakan administrator pendidikan yang memberdayakan berbagai sumber (manusia, sarana dan prasarana serta berbagai media pendidikan lainnya) secara optimal, relevan, efektif dan efisien guna menunjang pencapaian tujuan pendidikan (E. Mulyasa, 2004: 56). Sebagai administrator Kepala Madrasah melibatkan komponen manusia dengan berbagai potensinya dan juga komponen-komponen sarana parasarana dengan berbagai jenisnya untukmencapai tujuan pendidikan. Di samping itu, Kepala Madrasah juga sebagai guru senior yang dipandang memiliki kualifikasi yang sesuai untuk mendayagunakan sumber daya yang tersedia secara produktif untuk mencapai tujuan yang ditetapkan. Kepala Madrasah juga bertanggung jawab menciptakan lingkungan belajar yang kondusif yang memungkinkan SDM di sekolah mengembangkan potensinya secara optimal.

Dalam Islam banyak ayat atau hadis yang mengutarakan tentang perubahan dalam meningkatkan mutu pendidikan. Hal ini sesuai dengan firman Allah dalam Surat Al-Ra'du Ayat 11:

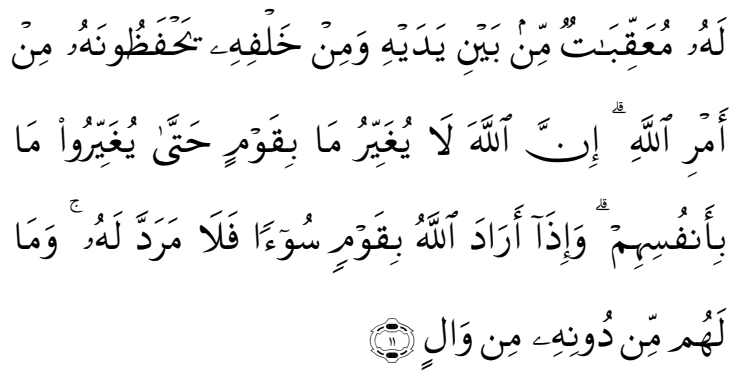

"Bagi manusia ada malaikat-malaikat yang selalu mengikutinya bergiliran, di muka dan di belakangnya, mereka menjaganya atas perintah Allah.Sesunggubnya Allab tidak merobah keadaan sesuatu kaum sehingga mereka merobah keadaan yang ada pada diri mereka sendiri. Dan 
apabila Allah menghendaki keburukan terhadap sesuatu kaum, maka tak ada yang dapat menolaknya; dan sekali-kali tak ada pelindung bagi mereka selain Dia.

Islam memandang bahwa budaya pendidikan harus mampu menyiapkan sumber daya manusia yang tidak sekedar sebagai penerima arus informasi global, tetapi juga harus memberi bekal kepada mereka agar dapat mengolah, menyesuaikan dan mengembangkan segala hal yang diterima melalui arus informasi tersebut. Budaya sekolah diharapkan juga mampu menjadi ujung tombak keberhasilan pendidikan untuk mencapai tujuan bersama yaitu Muslim yang ber-IPTEK dan berIMTAQ. Maka dari itu diperlukan suatu bentuk pengelolaan budaya sekolah yang sesuai dengan tuntunan ajaran Islam, yaitu manajemen kerja sekolah yang berbudaya islami. Adapun, strategi atau pendekatan yang dipakai dalam penerapan budaya Islami ini ditekankan pada suatu model seruan atau ajakan yang bijaksana untuk membentuk sikap manusia (Afektif) bersinergi dengan ajaran islam (Nanang Fattah, 2004: 2).

Budaya Kerja adalah suatu falsafah yang didasari oleh pandangan hidup sebagai nilai-nilai yang menjadi sifat, kebiasaan dan kekuatan pendorong, membudaya dalam kehidupan suatu kelompok masyarakat atau organisasi, kemudian tercermin dari sikap menjadi perilaku, kepercayaan, cita-cita, pendapat dan tindakan yang terwujud sebagai "kerja" atau "bekerja". Melaksanakan budaya kerja mempunyai arti yang sangat dalam, karena akan merubah sikap dan perilaku sumber daya manusia untuk mencapai produktivitas kerja yang lebih tinggi dalam menghadapi tantangan masa depan. Budaya kerja Islam haruslah bermotivasikan, dinamisme dan memupuk sifat dinamik untuk memimpin. Pekerja akan menyadari potensi dan kekuatan yang dikaruniakan Allah kepadanya seperti daya cipta, akal, pemkikiran asli, bakat yang tersendiri, kemampuan menggunakan alatalat tertentu dan sebagainya. Itulah yang dinamakan budaya kerja dalam persepektif Islam. Kerja pada hakekatnya adalah manifestasi amal kebajikan. Sebagai sebuah amal, maka niat dalam menjalankannya akan menentukan penilaian.

Budaya kerja umat Islam dalam masa globalisasi saat ini, banyak perusahaan yang mengadopsi budaya-budaya asing karena diyakini bagitu maju dan berkembang. Budaya asing tidak selamanya negatif maupun positif, dengan catatan sesuai dengan Islam.Budaya penghargaan atas waktu dan ketepatan dalam memenuhi janji, selalu dianggap sebagai budaya asing, padahal itu adalah bagian dari ajaran Islam (Hafidhuddin dan Tanjung, 2003: 64).

Menurut Kepala Kementerian Agama Kabupaten Tanah Datar, Bahwa MAS Salimpaung merupakan salah satu sekolah swasta yang menjadi prioritas utama untuk dibimbing dan disiapkan menjadi sekolah negeri (Dokumentasi MAS Salimpaung, 06 Februari 2018). Salah satu siswa kelas XII yang peneliti wawancarai juga menambahkan, Kebanyakan para siswa pada awal masuk, yang belajar di MAS Salimpaung merasa berat untuk mengikuti disiplin khususnya budaya Islami. Para siswa dituntut untuk mengamalkan segala teori yang telah dipelajari untuk di amalkan dalam kehidupan sehari-sehari di sekolah. Seperti kewajiban mencium tangan sebelum masuk kelas, melaksakan sholat dhuha, sholat zuhur berjamaah, membaca doa setiap masuk WC, tempat ibadah dan lain sebagainya. 
Kewajiban berbudaya Islami bukan untuk siswa saja, guru juga diharapkan berprilaku dan berbudaya islami di lingkungan sekolah (Hasil wawancara dengan siswa kelas XII MAS Salimpaung Kabupaten Tanah Datar, Senin, 05 Februari 2018).

Guru Akidah Akhlak juga menambahkan, kami akan mengecek setiap kegiatan siswa yang berbentuk islami, baik di lingkungan sekolah maupun di luar lingkungan sekolah. Hasil pengecekan tersebut akan dijadikan sebagai barometer awal untuk menentukan kelulusan siswa ke tingkat selanjutnya. Sekolah mengharapkan agar siswa yang belajar di MAS Salimpaung dapat berprilaku Islami sehingga membentuk budaya Islami di manapun para siswa berada. Oleh karena itu, sangat dituntut kepada guru agar berbudaya Islami di lingkungan sekolah, para guru juga diharapkan agar menjadi suri tauladan dalam bekerja secara islami (Hasil wawancara dengan Guru Akidah Akhlak MAS Salimpaung Kabupaten Tanah Datar, Selasa, 06 Februari 2018).

\section{KAJIAN TEORI}

\section{Manajemen Kerja}

Dalam bahasa Arab, manajemen disebutkan dengan idarah, diambil dari kata adartasy syai'ah atau perkataan adarta bibi juga didasarkan pada ad-dauran. Pengamat bahasa menilai adarta bibiitulah yang lebih tepat. Dalam al Qur'an hanya ada kata tabdir, merupakan bentuk masdar dari dabbara, yudabbiru, tadbiran. Tadbir berarti penerbitan, pengaturan, pengurusan, perencanaan dan persiapan. (Muhammad Bukhori, 2005: 175)

Sedangkan kata manajemen yang berasal dari bahasa latin, yaitu kata manus dan agree yang berarti malakukan. Kata-kata itu digabung menjadi kata kerja managere yang artinya menangani. Managere diterjemahkan dalam bahasa Inggris dalam bentuk kata kerja to manage, dengan kata benda dengan management, dan manager untuk orang yang melakukan kegiatan manajemen. Akhirnya manajemen diterjemahkan dalam bahasa Indonesia menjadi manajemen atau pengelolaan (Usman, 2006: $3)$.

Menurut Malayu S.P Hasibuan, mendefinisikan manajemen adalah ilmu dan seni yang mengatur proses pemanfaatan sumber daya manusia dan sumber sumber lainnya secara efektif dan efisien untuk mencapai suatu tujuan tertentu (Hasibuan, 1990: 3). Sedangkan menurut G.R.Terry dalam bukunya "Principel Management" mendefinisikan manajemen merupakan suatu proses yang terdiri dari tindakantindakan perencanaan, pengorganisasian, mengerakkan dan mengendalikan, yang dilakukan untuk menentukan serta mencapai sasaran yang telah ditentukan melalui pemanfaatan sumber daya manusia dan sumber daya lainnya (Hasibuan, 1990: 3).

Manajemen kerja pada dasarnya merupakan manajemen dalam mengelola sumber daya yang berorientasi pada kinerja yang melakukan proses komunikasi secara terbuka dan berkelanjutan dengan tujuan mencapai visi dan misi bersama dengan strategis yang baik serta terpadu sebagai kekuatan pendorong untuk mencapai tujuan lembaga pendidikan. Manajemen kerja adalah suatu proses yang dirancang untuk meningkatkan kinerja lembaga pendidikan yang digerakkan oleh Kepala Madrasah (Dharma, 2005 : 1).

Manajemen kerja mencakup pengkajian ulang terhadap kinerja secara berkesinam- 
bungan dan dilakukan secara bersama berdasarkan kesepakatan mengenai sasaran, keahlian, kompetensi, rencana kerja dan pengembangan, serta pengimplementasian rencana peningkatan dan pengembangan lebih lanjut dalam dunia pendidikan (Dharma, 2005: 2). Sedangkan penilaian kerja merupakan alat yang bermanfaat untuk mengevaluasi kerja para guru dan pegawai Madrasah, juga untuk mengembangkan dan memotivasi. Pada intinya, penilaian kerja dapat dianggap sebagai alat untuk memverifikasi bahwa guru memenuhi standar kinerja yang telah ditetapkan. Penilaian kinerja dapat pula merupakan cara untuk membantu mengelola kinerja mereka (Herman Sofyandi, 2008: 122).

Keberhasilan kerja akan membawa dampak positif terhadap hasil yang efektif dan mampu mencapai tujuan dari lembaga pendidikan. Oleh karenanya, lembaga pendidikan yang melakukan manajemen kerja pada Madrasah akan mampu memperoleh kinerja guru yang efektif. Tantangan yang dihadapi dalam menjalankan majemen kerja adalah karna adanya alasan masingmasing. Bagi Kepala Madrasah manajemen kerja merupakan tambahan beban kerja, disamping menjalankan tugas lain. Sementara itu, dipihak guru dan pegawai, masih banyak keraguan karena belum memahami sepenuhnya akan manfaat manajemen kerja bagi dirinya sendiri (Dermawan Wibisono: 2006: 43).

Suatu lembaga pendidikan dibentuk untuk mencapai tujuan Madrasah yang menunjukkan hasil kerja dan prestasi yang baik. Untuk menjamin agar aktivitas tersebut dapat mencapai hasil yang diharapkan, diperlukan upaya manajemen dalam pelaksanaan aktivitasnya. Dengan demikian, hakikat manajemen kerja adalah bagaimana mengelola seluruh kegiatan Madrasah untuk mencapai tujuan Madrasah yang telah ditetapkan. Bagi Kepala Madrasah manfaat manajemen kerja antara lain mengupayakan kinerja guru untuk menggunakan waktu secara berkualitas, memperbaiki sistim belajar dan membantu guru yang kurang mampu dalam memacu semangat belajar,

Manajemen kerja mendukung Seberapa baik pimpinan mengelola kinerja guru yang akan secara langsung mempengaruhi kerja masing-masing guru secara individu dan juga kinerja seluruh lembaga pendidikan. Manajemen kerja dalam lembaga pendidikan memiliki berbagai tujuan dan fungsi yang dapat membantu kefektifan dan keefisienan kerja. Dengan tujuan menciptakan budaya memikul tangggung jawab dalam peningkatan proses kerja dan kemampuan yang berkesinambungan (Herman Sofyandi, 2008: 122).

\section{Kepala Madrasah}

Kata "kepala" dapat diartikan "ketua" atau "pemimpin" dalam suatu organisasi atau sebuah lembaga. Sedangkan "Madrasah" adalah sebuah lembaga dimana menjadi tempat menerima dan memberi pelajaran. Menurut pendapat Wahjosumidjo yang ditulis dalam buku Kepemimpinan Kepala Madrasah atau Kepala Sekolah, bahwa pengertian di atas dapat didefinisikan bahwa Kepala Madrasah adalah sebagai berikut:

"Seorang tenaga fungsional guru yang diberi tugas untuk memimpin suatu Madrasah dimana diselenggarakan proses belajar mengajar, atau tempat dimana terjadi interakasi antara guru yang memberi pelajaran dan murid yang 
menerima pelajaran" (Wahjosumidjo: 2005: 83).

Kepala Madrasah merupakan jabatan pemimpin yang tidak bisa diisi oleh orangorang tanpa didasarkan atas pertimbanganpertimbangan.Dalam pengertian lain Kepala Madrasah merupakan salah satu komponen pendidikan yang paling berperan dalam meningkatkan kualitas pendidikan (E. Mulyasa, 2005: 160). Kepala Madrasah adalah penanggung jawab atas penyelenggaraan pendidikan, administrasi Madrasah, pembinaan tenaga pendidikan lainnya, pendayagunaan serta pemeliharaan sarana dan prasarana juga sebagai supervisor pada Madrasah yang dipimpinnya.

Kepala Madrasah adalah seorang manager. Dialah yang mengatur segala sesuatu yang ada di Madrasah untuk mencapai tujuan Madrasah. Dengan posisi sebagai manager, Kepala Madrasah mempunyai kewenagan penuh terhadap arah kebijakan yang ditempuh menuju visi dan misi Madrasah.Kepala Madrasah sebagai manager merupakan pencerminan dari kepemimpinan Kepala Madrasah.Tetapi Kepala Madrasah sebagai penguasa cenderung pada pencermina egoisme diri.Karena itu dalam suatu organisasi ini sungguh tidak dapat diterapkan. Karena organisasi adalah kegiatan bersama menuju sebuah tujuan, tidak boleh dikelola atas dasar egoisme, kedirian seseorang, melainkan dikelola oleh seseorang pemimpin (Muhammad Saroni, 2006: 21).

Kunci keberhasilan suatu Madrasah pada hakikatnya terletak pada efisiensi dan efektivitas penamplan seorang Kepala Madrasah. Keberhasilan Madrasah adalah keberhasilan Kepala Madrasah. Dan keberhasilan Kepala Madrasah adalah keberhasilan Madrasah. Pada saat ini masalah
Kepala Madrasah merupakan suatu peran yang menuntut persyaratan kualitas kepemimpinan yang kuat. Bahkan telah berkembang menjadi tuntutan yang meluas dari masyarakat sebagai kriteria keberhasilan Madrasah diperlukan adanyan kepemimpinan Kepala Madrasah yang berkualitas.

Perilaku dan budaya kerja islami Kepala Madrasah merupakan tindakan-tindakan spesifik seorang pemimpin dalam mengarahkan dan mengkoordinas kerja anggota kelompok menurut budaya yang islami. Menurut pendapat Mulyadi dalam bukunya tentang Kepemimpinan Kepala Madrasah, yang menyatakan bahwa perilaku kepemimpinan Kepala Madrasah yang berbudaya kerja islami dalam melaksanakan tugas-tugasnya meliputi aktivitas sebagai berikut:

a. Mengambil keputusan.

b. Mengembangkan imajinasi.

c. Mengembangkan kesetiaan pengikutnya.

d. Pemrakarsa, penggiatan dan pengendaian rencana.

e. Memanfaatkan sumber daya manusia dan sumber-sumber lainnya.

f. Melaksanakan kontrol dan perbaikanperbaikan atas kesalahan.

g. Memberikan tanda penghargaan.

h. Mendelegasikan wewenang kepada bawahannya.

i. Pelaksanaan keputusan dengan memberikan dorongan kepada paara pengikut (Mulyadi, 2010: 16).

Kepala Madrasah dan lingkungan selanjutnya yang berperan dalam pewarisan nilai-nilai dan budaya dalam pendidikan Islam adalah Madrasah (madrasah) sebagai sebuah sistem dan struktur sosial pendidikan (Fatah, 2004: 6). Dalam lingkungan ini akan terjadi proses sosial antara pendidik dan anak didik. 
Menurut Muhammad Athiyah alAbrasyi nilai-nilai dan budaya yang harus ditonjolkan oleh pandidik dalam lingkungan Madrasah (madrasah) antara lain: zuhud, bersih, ikhlas, pemaaf, berfungsi sebagai orang tua bagi peserta didik, memahami akhlak anak didik, menguasai bidang yang diajarkan, dan lain-lainnya. Nilai-nilai dan budaya tersebut akan mengakar terhadap peserta didik jika pendidik mencontohkannya melalui pola dan tingkah laku dalam proses sosial di Madrasah. Sebab pendidik adalah idola bagi anak didiknya, pemberi contoh yang sangat cepat dicerna oleh peserta didik, bahkan tidak jarang pendidik menjadi tumpuan bagi orang tua didik untuk membina dan mengembangkan mental dan moral anaknya. Kepala Madrasah dan lingkungan masyarakat menjadi media pewarisan nilai-nilai dan budaya menurut pendidikan Islam karena setiap orang akan hidup di tengah masyarakat. Oleh sebab itu peranan para tokoh agama sangat diharapkan untuk dapat mengendalikan nilai-nilai dan budaya masyarakat menuju nilai-nilai dan budaya yang Islami.

\section{Budaya Kerja Islami}

Budaya adalah segala nilai, pemikiran, serta simbol yang mempengaruhi perilaku, sikap, kepercayaan, serta kebiasaan seseorang dan masyarakat (Ujang Sumarwan, 2003: 170). Contohnya adalah budaya tepat waktu.Rasulullah SAW menjelaskan bahwa waktu adalah sesuatu yang sangat berharga yang tidak boleh diabaikan. Rasulullah SAW memberikan contoh bagaimana beliau menyikapi ketepatan waktu, kemudian diikuti oleh para sahabat beliau.Akhirnya, sahabat menyadari dan terbiasa untuk menghargai waktu (Hafidhuddin dan Tanjung, 2003: 59).

Pengertian budaya pada umumnya, mengandung gejala sosial atau gejala kelompok yang mencolok. Dalam setiap kelompok yang melakukan bekerja sama (team work) secara terorganisasi, maka akan muncul kepermukaan keinginan kelompok untuk mendapatkan pelayanan dari perusahaannya terhadap berbagai kebutuhan dan aspirasi kelompok. Budaya Kerja adalah suatu falsafah yang didasari oleh pandangan hidup sebagai nilai-nilai yang menjadi sifat, kebiasaan dan kekuatan pendorong, membudaya dalam kehidupan suatu kelompok masyarakat atau organisasi, kemudian tercermin dari sikap menjadi perilaku, kepercayaan, cita-cita, pendapat dan tindakan yang terwujud sebagai "kerja" atau "bekerja". Melaksanakan budaya kerja mempunyai arti yang sangat dalam, karena akan merubah sikap dan perilaku sumber daya manusia untuk mencapai produktivitas kerja yang lebih tinggi dalam menghadapi tantangan masa depan.

Budaya kerja Islam haruslah bermotivasikan, dinamisme dan memupuk sifat dinamik untuk memimpin. Pekerja akan menyadari potensi dan kekuatan yang dikaruniakan Allah kepadanya seperti daya cipta, akal, pemkikiran asli, bakat yang tersendiri, kemampuan menggunakan alatalat tertentu dan sebagainya. Itulah yang dinamakan budaya kerja dalam persepektif Islam.Kerja pada hakekatnya adalah manifestasi amal kebajikan. Sebagai sebuah amal, maka niat dalam menjalankannya akan menentukan penilaian. Budaya kerja umat Islam dalam masa globalisasi saat ini, banyak perusahaan yang mengadopsi budaya-budaya asing karena diyakini bagitu maju dan berkembang.Budaya asing tidak 
selamanya negatif maupun positif, dengan catatan sesuai dengan Islam.Budaya penghargaan atas waktu dan ketepatan dalam memenuhi janji, selalu dianggap sebagai budaya asing, padahal itu adalah bagian dari ajaran Islam (Hafidhuddin dan Tanjung, 2003: 64).

Budaya kerja Islam berarti mengaktualisasikan seluruh potensi iman, pikir, dan zikir, serta keilmuan kita untuk memberikan nilai kebahagiaan. Inti atau sumber inspirasi budaya Islam adalah Alqur'an dan sunnah Rasululllah SAW, yang diikat dalam satu kata, yaitu akhlak. Dalam Islam, manusia dituntut untuk minta tolong pada Allah dan mengakui keterbatasan dirinya. Allah lebih mencintai orang-orang yang selalu meminta dari pada yang enggan meminta, karena seolah-olah manusia itu berkecukupan.

Apabila manusia rajin bekerja dan berupaya, ia akan menciptakan budaya kerja yang disiplin, keras kemauan dan tidak cepat putus asa. Sementara itu, individu itu terus menerus berdoa dan meminta tolong dan ridho-Nya, agar usahanya membuahkan hasil. Sifat ini akan membawa manusia ke perilaku rendah hati, takut, takabur dan senantiasa menyadari baik kelemahan maupun kekuatannya.

Budaya kerja umat Islam dalam masa globalisasi saat ini, banyak perusahaan yang mengadopsi budaya-budaya asing karena diyakini bagitu maju dan berkembang. Budaya asing tidak selamanya negatif maupun positif, dengan catatan sesuai dengan Islam.Budaya penghargaan atas waktu dan ketepatan dalam memenuhi janji, selalu dianggap sebagai budaya asing, padahal itu adalah bagian dari ajaran Islam (Hafidhuddin dan Tanjung, 2003: 64).

124 Jurnal al-Fikrah, Vol. VII, No. 2 Juli-Desember 2019

\section{METODE PENEUTAN}

Penelitian ini termasuk dalam kategori penelitian lapangan (field research). Penelitian ini menggunakan pendekatan penelitian kualitatif, yaitu jenis penelitian yang menghasilkan penemuan-penemuan yang tidak dapat diperoleh dengan menggunakan prosedur-prosedur statistik atau dengan cara kuantifikasi lainnya. Melalui penelitian kualitatif peneliti dapat mengenali subjek dan merasakan apa yang mereka alami dalam kehidupan sehari-hari. Menurut definisi ini penelitian kualitatif menghasilkan data deskriptif sehingga merupakan rinci dari suatu fenomena yang diteliti (Basrowi Sudikin, 2002: 1).

Pemilihan sumber data tidak berdasarkan kedekatan emosional, partner, dan lainlainnya yang dapat memengaruhi objektivitas dari perolehan data, akan tetapi adalah murni karena sesuai dengan kepentingan permasalahan dan tujuan penelitian. Sebagaimana Moleong berpendapat bahwa informan adalah orang-orang yang dipilih sesuai dengan kepentingan permasalahan dan tujuan penelitian (Lexy J. Moleong, 2002: 135).

Karakteristik sumber data pada penelitian ini adalah dilihat dari keutamaan objek untuk memperoleh informasi yang lebih objektif. Sumber data dibagi kepada dua bagian, yaitu sumber data primer, yaitu kepala sekolah dan guru pada sekolah tersebut. Sumber data sekunder adalah sebagai data pendukung yang terkait dengan penelitian ini, yaitu para siswa, dan pegawai tata usaha yang mana sumber data berjumlah tiga belas orang, dan yang peneliti anggap berhubungan dengan manajemen kerja Kepala Madrasah dalam menerapkan budaya islami di MAS Salimpaung Kabupaten Tanah Datar. Untuk 
menggali informasi dan mendapatkan data dari sumber data digunakan teknik snow ball sampling di mana informan dapat bertambah sesuai kebutuhan sampai diperoleh data yang valid. Hal ini sejalan dengan pendapat Lexy J. Moleong yang dikutip oleh Ridwan mengatakan bahwa jumlah informan boleh bertambah bergantung sesuai dengan keperluan peneliti berdasarkan teknik snow ball sampling (bola salju) (Ridwan, 2004: 104).

Dalam penelitian data kualitatif salah satu modelnya adalah Model Miles dan Huberman dalam Hanafi, yaitu analisis data kualitatif dilakukan secara interaktif dan berlangsung secara terus-menerus dari mulai pengumpulan data di lapangan sampai selesai, tuntas dan jenuh. Langkahnya dilakukan: (1) pengumpulan data, (2) reduksi data, (3) display data, dan (4) kesimpulan (Hanafi, Abdul Halim. 2013: 123). Uji keabsahan data dalam penelitian kualitatif meliputi uji credibility (validitas internal), transferability (validitas eksternal), dependability (reliabilitas), dan confirmability (objektivitas) (Sugiyono, 2005: 133-139).

\section{HASIL PENEUTIANDANPEMBAHASAN}

Keberadaan Madrasah Aliyah Swasta (MAS) Salimpaung kecamatan Salimpaung Kabupaten Tanah Datar Propinsi Sumatera Barat, merupakan lanjutan Pendidikan Islam pada zaman lampau. Pada tahun 1934 di kenagarian Salimpaung sudah berdiri sebuah Madrasah yang bernama Madrasatul Falah, Madrasah ini didirikan oleh Buya $\mathrm{H}$. Jusan Toha dan Buya H. Abdul Hakim. Madrasah tersebut akhirnya terpaksa tutup pada tahun 1942, karena masuknya tentara Jepang ke Indonesia yang berlanjut dengan perang kemerdekaan Bangsa Indonesia (Dokumentasi MAS Salimpaung Kabupaten Tanah Datar, Senin, 05 Februari 2018).
Pada tahun 1950 berdiri pula Sekolah Menengah Pertama Islam (SMPI) di Jorong nan IX dalam kenagarian Salimpaung oleh Buya Muhammad Rasyad Yahya. Muridmurid sekolah tersebut berdatangan dari Nagari-nagari tetangga, seperti Rao-rao, Supayang, Lawang Mandahiling dan sekitarnya. Pada tahun 1952, SMPI tersebut terbagi dua yaitu SMPI dan Madrasah Muallimin. Dengan berdirinya Madrasah Muallimin di Salimpaung (di lokasi Puskesmas Salimpaung sekarang). Dua Madrasah yang parallel setingkat SLTP pada awalnya berjalan mulus dalam Kenagarian Salimpaung, tetapi karena minimnya dana dari masyarakat dan pengolakan daerah, maka sekolah tersebut harus dilebur menjadi Madrasah Menengah Pertama (MMP) sampai tahun 1958 (Dokumentasi MAS Salimpaung Kabupaten Tanah Datar, Senin, 05 Februari 2018).

Pada tahun 1960, berdiri lagi sebuah Madrasah, yaitu Madrasah Tarbiyah Islamiyah (MTI) di Jorong Koto Tuo (Dalam kenagarian Salimpaung) oleh buya H.Abdul Hakim. Namun Madrasah ini tidak berumur lama karena pendirinya meninggal dunia, tidak ada tenaga penganti beliau dan minimnya dana masyarakat. Membaca perkembangan Madrasah di Kenagarian Salimpaung pada zaman lampau yang silih berganti hidup dan mati disatu sisi dan semangat masyarakat tidak pernah padam, supaya Madrasah hidup kembali, maka atas kesepakatan beberapa tokoh masyarakat yang peduli pada pendidikan, maka melalui Masjid Raya Salimpaung didirikanlah sebuah Madrasah setingkat SLTA yaitu Madrasah Aliyah Swasta (MAS) Salimpaung. Dengan harapan terbesar mudah mudahan MAS ini mampu mewujudkan generasi Islam masa depan yang 
beriman, berilmu dan bertaqwa serta berakhlak mulia di tengah-tengah masyarakat. Madrasah ini dikelola oleh sebuah yayasan yang lahir dari Masjid Raya Salimpaung yaitu Yayasan Ulul Albab Masjid Raya Salimpaung (YUAMRA) (Dokumentasi MAS Salimpaung Kabupaten Tanah Datar, Senin, 05 Februari 2018).

Jumlah siswa madrasah ini meningkat dari tahun ke tahun hingga saat ini. Mereka selain berasal dari Kecamatan Salimpaung, Juga berasal dari Kecamatan tetangga, Kecamatan Tanjung Baru, Kecamatan Sungai Tarab, bahkan juga dari luar Kecamatan lain di Kabupaten dan propinsi Sumatera Barat. Siswa-siswa yang telah tamat dari Madrasah ini, telah dapat menduduki bangku kuliah di berbagai perguruan tinggi, baik negeri maupun swasta di Sumatera Barat, seperti perguruan tinggi "Baitur Ridwan" Bukittinggi, PGSD/PGTKI Batusangkar, STAIN Muhmud Yunus Batusangkar, sekarang sudah menjadi IAIN Batusangkar, IAIN Iman Bonjol Padang, sekarang sudah menjadi UIN Imam Bonjol Padang, Universitas Negeri Padang (UNP) dan lainnya (Dokumentasi MAS Salimpaung Kabupaten Tanah Datar, Senin, 05 Februari 2018).

Perumusan manajemen kerja Kepala Madrasah dalam menerapkan budaya Islami di MAS Salimpaung Kabupaten Tanah Datar dilakukan oleh pihak yayasan, komite dan beberapa guru yang terkait. Hasil perumusan yaitu: kegiatan rutin, spontan, keteladanan dan pengkondisian. Perumusan dilaksakan di sekolah dengan mengalami 3 kendala, (1). Tidak terdapat rujukan program sebagai pembanding, (2). Tidak dihadirkan orang yang berpengalaman dalam merumuskan, dan (3). Kurang tepatnya waktu musyawarah, karena dilaksakan pada sore hari.

Madrasah dipandang sebagai suatu organisasi yang membutuhkan pengelolaan, karena inti dari Madrasah adalah mengelola sumber daya manusia (SDM) yang untuk menghasilkan lulusan yang berkualitas, sesuai dengan tuntutan kebutuhan masyarakat, serta pada gilirannya lulusan sekolah diharapkan dapat memberikan kontribusi kepada pembangunan bangsa (Nanang Fattah,2003: 2).

Kepala Madrasah sebagai top leader sebuah Madrasah mempunyai peranan penting sebagai pemimpin dalam mengelola SDM pada Madrasah yang dipimpinnya. Disamping itu bertanggung jawab atas keseluruhan prilaku manajemen yang terjadi di sekolah. Melalui pengontrolan secara terus menerus dan sistematis terhadap berbagai hal, seperti kurikulum, sarana prasarana, kesiswaaan dan lain-lain. Kepala Madrasah juga merupakan administrator pendidikan yang memberdayakan berbagai sumber (manusia, sarana dan prasarana serta berbagai media pendidikan lainnya) secara optimal, relevan, efektif dan efisien guna menunjang pencapaian tujuan pendidikan (E. Mulyasa, 2004: 56).

Maka dari itu diperlukan suatu bentuk pengelolaan budaya sekolah yang sesuai dengan tuntunan ajaran Islam, yaitu manajemen kerja sekolah yang berbudaya islami. Adapun, strategi atau pendekatan yang dipakai dalam penerapan budaya Islami ini ditekankan pada suatu model seruan atau ajakan yang bijaksana untuk membentuk sikap manusia (Afektif) bersinergi dengan ajaran islam (Nanang Fattah, 2003: 2). Implementasi manajemen kerja Kepala Madrasah dalam menerapkan budaya islami di MAS Salimpaung 
Kabupaten Tanah Datar, meliputi Kegiatan rutin yang berjalan di MAS Salimpaung diantaranya seperti setiap pagi, berdo'a sebelum dan sesudah pelajaran, sholat dhuha, hafalan surat, dan sholat dzuhur. Kegiatan ini termasuk kegiatan harian, sedangkan kegiatan mingguan seperti muhadharah yang diikuti oleh semua warga sekolah bulanan seperti setiap tiga bulan sekali diadakan kemah tahfidz siswa dan guru. Kegiatan tahunan seperti mabid dibulan ramadhan, perayaan Idul fitri dan Idul Adha.

Cara mengevaluasi manajemen kerja Kepala Madrasah dalam menerapkan budaya Islami di MAS Salimpaung Kabupaten Tanah Datar dilakukan dengan mengkaji lebih dalam terhadap kendalakendala yang ditemukan di lapangan, serta mengadakan rapat evaluasi 1 bulan sekali bersama pihak yayasan MAS Salimpaung.

\section{PENUTUP}

\section{Kesimpulan}

Perumusan manajemen kerja Kepala Madrasah dalam menerapkan budaya Islami di MAS Salimpaung Kabupaten Tanah Datar dilakukan oleh pihak yayasan, komite dan beberapa guru yang terkait. Hasil perumusan yaitu: kegiatan rutin, spontan, keteladanan dan pengkondisian. Perumusan dilaksakan di sekolah dengan mengalami 3 kendala, (1). Tidak terdapat rujukan program sebagai pembanding, (2). Tidak dihadirkan orang yang berpengalaman dalam merumuskan, dan (3). Kurang tepatnya waktu musyawarah, karena dilaksakan pada sore hari.

Implementasi manajemen kerja Kepala Madrasah dalam menerapkan budaya islami di MAS Salimpaung Kabupaten Tanah
Datar, meliputi Kegiatan rutin yang berjalan di MAS Salimpaung diantaranya seperti setiap pagi, berdo'a sebelum dan sesudah pelajaran, sholat dhuha, hafalan surat, dan sholat dzuhur. Kegiatan ini termasuk kegiatan harian, sedangkan kegiatan mingguan seperti muhadharah yang diikuti oleh semua warga sekolah bulanan seperti setiap tiga bulan sekali diadakan kemah tahfidz siswa dan guru. Kegiatan tahunan seperti mabid dibulan ramadhan, perayaan Idul fitri dan Idul Adha.

Cara mengevaluasi manajemen kerja Kepala Madrasah dalam menerapkan budaya Islami di MAS Salimpaung Kabupaten Tanah Datar dilakukan dengan mengkaji lebih dalam terhadap kendalakendala yang ditemukan di lapangan, serta mengadakan rapat evaluasi 1 bulan sekali bersama pihak yayasan MAS Salimpaung.

\section{Saran}

a. Diharapkan kepada Kepala Madrasah MAS Salimpaung beserta yayasan agar menyusun perumusan manajemen kerja Kepala Madrasah dalam menerapkan budaya islami di MAS Salimpaung Kabupaten Tanah Datar dengan cara melibatkan orang berkompetensi dan mempunyai pengalaman yang sesuai dengan bidangnya.

b. Diharapkan kepada Madrasah MAS Salimpaung beserta yayasan mengimplementasikan manajemen kerja Kepala Madrasah dalam menerapkan budaya islami di MAS Salimpaung Kabupaten Tanah Datar dengan cara melibatkan masyarakat, Kementerian Agama dan Dinas Pendidikan.

c. Diharapkan kepada Kepala Madrasah MAS Salimpaung, yayasan, Pengawas, Dinas pendidikan, Kementerian Agama, 
masyarakat serta semua pihak yang terkait, untuk melakukan pengontrolan secara kontiniutas dan bersama terhadap semua program yang telah dilaksanakan dan sekaligus mengevaluasi semua program untuk perbaikan ke depannya.

\section{KEPUSTAKAAN ACUAN}

Basrowi dan Sukidin, 2002, Metode Penelitian Kualitatif Perspektif Mikro, (Surabaya. Insan Cendikia)

Basrowi, Sudikin. 2002, Metode Penelitian Kualitaif Perspektif Mikro, (Surabaya. Insan Cendekia.)

Dermawan Wibisono, 2002, Manajemen Kinerja, (Jakarta. Erlangga)

E. Mulyasa, 2004,

Manajemen Berbasis Sekolab; Konsep, St rategi Dan Implimentasi, (Bandung: Remaja Rosda Karya Offset)

E.Mulyasa, 2005, Menjadi Guru Profesional, (Bandung. Remaja Rosda Karya)

Hafidhuddin Didin, Hendri Tanjung, 2003, Manajemen Syariah dalam Praktik, (Jakarta. Gema Insani)

Hanafi, Abdul Halim, 2013, Metodologi Penelitian Kependidikan, (Batusangkar: STAIN Batusangkar Press)

Herman Sofyandi, 2008, Manajemen Sumber Daya Manusia, (Yogyakarta: Graha Ilmu)

Husaini Usman, 2006, Manajemen Teori, Praktik, Dan Riset Pendidikan, (Ja karta: Bumi Aksara)
Lexy J. Moleong, 2002, Metodologi Penelitian Kualitatif, (Bandung: Remaja Rosdakarya)

Malayu S.P Hasibuan, 1990, Manajemen Das ar, Pengetian, dan Masalah (Jakarta: CV. Haji Mas Agung)

Muh. Ridwan, 2004, Manajemen Baitul Maal wa Tanwil (BMT), (Yogyakarta: UII Press)

Muhamad Saroni. 2006, Manajemen Madrasah, (Yogyakarta: Ar Russ)

Muhammad Bukori, 2005, AzasAzas Manajemen, (Yogyakarta: Aditya Media)

Mulyadi, 2010, Sistem Akuntansi (Jakarta: Salemba Empat)

Nanang Fattah, 2004, Landasan Manajemen Pendidikan, (Bandung: PT Remaja Rosda Karya)

Sugiyono, 2005, Memahami Penelitian Kualitatif, (Bandung: Alfabeta)

Surya Dharma, 2005, Manajemen Kinerja, (Yogyakarta: Pustaka Pelajar)

Ujang Sumarwan, 2003, Perilaku Konsumen. Teori dan Penerapannya dalam Pemasaran, (Jakarta: Ghalia Indonesia)

Undang Undang Republik Indonesia Nomor 20 Tahun 2003 Bab II, pasal 3

Wahjosumidjo, 2005, Kepemimpinan Kepala Sekolah, Tinjauan Teori dan Permasalabannya. (Jakarta: Raja Grafindo Persada). 